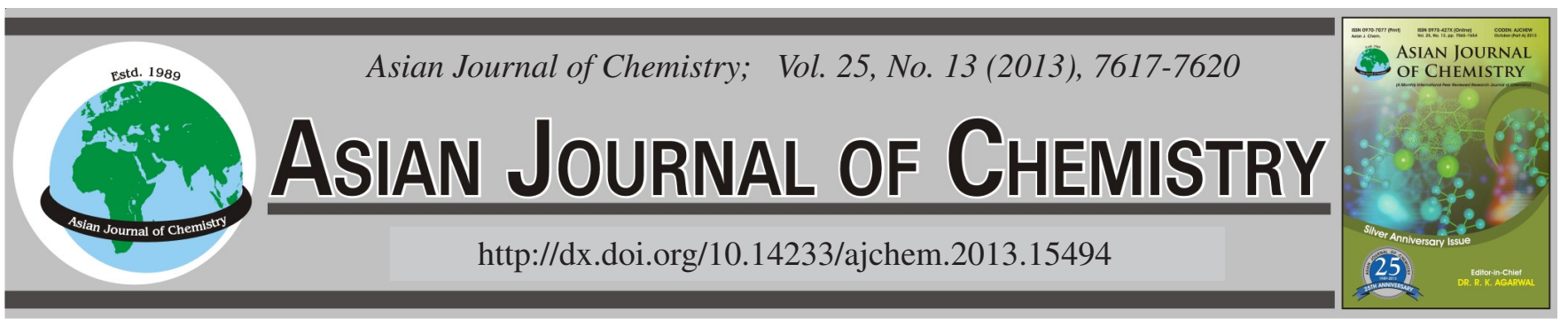

\title{
Study on Extraction Process of Curcuma zedoaria Volatile Oil and Its Effect on Anticancer
}

\author{
Shan-Bin Guo ${ }^{1}$, Yue Tian ${ }^{2}$ and Ling-Yan Jian ${ }^{1, *}$
}

\begin{abstract}
${ }^{1}$ Department of Pharmacy, Shengjing Hospital of China Medical University, Shenyang, P.R. China
${ }^{2}$ Department of Anesthesiology, Shengjing Hospital of China Medical University, Shenyang, P.R. China

*Corresponding author: Tel: +86 24 9661571101; E-mail: jianlingyan126@126.com; kangtg@ 126.com
\end{abstract}

(Received: 16 March 2013;

Accepted: 3 July 2013)

AJC-13764

\begin{abstract}
To investigate the extraction process of Curcuma zedoaria volatile oil and its effect on proliferation and apoptosis of human gastric cancer SGC-7901 cells. Orthogonal experimental method was used to analyze the effect of extraction factors-crushing degree, amount of added water and distillation time-on Curcuma zedoaria oil; MTT assay, PI staining and flow cytometry were used to study the effect of $C$ urcuma zedoaria oil on human gastric cancer SGC-7901 cells. The crushing degree, amount of added water and distillation time all affect the extraction of Curcuma zedoaria oil, Curcuma zedoaria oil can inhibit human gastric cancer SGC-7901 cell proliferation and induce its apoptosis.
\end{abstract}

Key Words: Curcuma zedoaria, Volatile oil, SGC-7901, Proliferation and apoptosis.

\section{INTRODUCTION}

Medicinal Curcuma zedoaria is the dried rhizome of Curcuma phaeocaulis Val., Curcuma kwangsiensis Lee et Liang or Curcuma wenyujin Chen et Ling that belong to Zingiberaceae plant family, the latter is often called "Curcuma wenyujin". Curcuma zedoaria mainly contains volatile oil constituents, the composition of its volatile oil is a variety of sesquiterpene derivatives and eucalyptol, of which curzerenone is the main component ${ }^{1}$, with its content around 1.0-2.5\%. Modern pharmacological studies have shown that the volatile oil of Curcuma zedoaria has pharmacological effects such as direct inhibition and destruction of cancer cells ${ }^{2}$, enhancement of immune activation, regulation of immune response and liver protection. Its volatile oil agents, as well as curcumol and curzerenone have a direct destructive effect on cancer cells ${ }^{3}$; these are effective material basis for the treatment of tumors by Curcuma zedoaria. Compared with many antitumor chemical drugs, Curcuma zedoaria extract is non-mutagenic, which is a relatively safe antitumor traditional Chinese medicine in clinical application. For further development and utilization of the composition of the volatile oil, we conducted a study on its extraction process and investigated the effects of herb crushing degree, extraction time and soaking time these three factors on volatile oil extraction yield. At the same time, human gastric cancer SGC-7901 cell was taken as the object of study to explore in depth the effect of extracted Curcuma zedoaria oil on proliferation, cell cycle and apoptosis of tumor cells.

\section{EXPERIMENTAL}

Curcuma zedoaria (purchased from Anguo crude drug market, identified as the dried rhizome of Curcuma Wenyujin Chen et Ling), volatile oil extractor, crusher (RT-34 desktop grinding-type), thermostat heater, medicinal screen, etc.

Optimization of Curcuma zedoaria powder extraction process using orthogonal design. The experiment was designed according to the $\mathrm{L}_{9}\left(3^{4}\right)$ orthogonal array, factors and levels are shown in Table-1. Curcuma zedoaria was smashed, (4-20) mesh, (20-40) mesh and (40-80) mesh Curcuma zedoaria powders were screened, respectively and certain amounts of water were added, respectively, volatile oil was determined. Determination of volatile oil of the "Chinese Pharmacopoeia", distillation was carried out till the amount of volatile oil was no longer increasing, after placing for $1 \mathrm{~h}$, amount of volatile oil was measured and extraction rates were calculated, the results are shown in Tables 2 and 3.

The results showed that the crushing degree, amount of added water, distillation time all have significant effects on oil extraction yield, the order of the effects according to the size was crushing degree $>$ amount of added water $>$ distillation time. The optimum extraction condition is $\mathrm{A} 3 \mathrm{~B} 3 \mathrm{C} 2$, i.e., crushing degree of (40-80) mesh, amount of added water of 40 folds and distillation time of $4 \mathrm{~h}$.

Curcuma zedoaria oil was extracted and obtained from this study, which was prepared in solutions containing $10,30,100 \mu \mathrm{g} / \mathrm{mL}$ of curcumol, respectively; human gastric 
TABLE-1

FACTORS AND LEVELS FOR Curcuma zedoaria VOLATILE OIL EXTRACTION PROCESS

\begin{tabular}{cccc}
\hline Level & A & B & C \\
\cline { 2 - 4 } & $\begin{array}{c}\text { Crushing degree } \\
\text { (mesh) }\end{array}$ & $\begin{array}{c}\text { Amount of added } \\
\text { water (fold) }\end{array}$ & $\begin{array}{c}\text { Distillation } \\
\text { time }\end{array}$ \\
\hline 1 & $4-20$ & 10 & 2 \\
2 & $20-40$ & 20 & 4 \\
3 & $40-80$ & 40 & 6 \\
\hline
\end{tabular}

TABLE-2

ORTHOGONAL TEST RESULTS FOR Curcuma zedoaria VOLATILE OIL EXTRACTION PROCESS

\begin{tabular}{ccccc}
\hline Test No. & A & B & C & Yield (\%) \\
\hline 1 & 1 & 1 & 1 & 0.68 \\
2 & 1 & 2 & 2 & 1.12 \\
3 & 1 & 3 & 3 & 1.48 \\
4 & 2 & 1 & 3 & 1.41 \\
5 & 2 & 2 & 1 & 0.85 \\
6 & 2 & 3 & 2 & 2.12 \\
7 & 3 & 1 & 2 & 1.38 \\
8 & 3 & 2 & 3 & 1.56 \\
9 & 3 & 3 & 1 & 1.98 \\
$\mathrm{~K}_{1}$ & 3.28 & 3.47 & 3.51 & - \\
$\mathrm{K}_{2}$ & 4.38 & 3.53 & 4.62 & - \\
$\mathrm{K}_{3}$ & 4.92 & 5.58 & 4.45 & - \\
$\mathrm{R}$ & 1.64 & 2.11 & 1.11 & - \\
\hline
\end{tabular}

\begin{tabular}{ccccc}
\hline \multicolumn{5}{c}{ TABLE-3 } \\
VARIANCE ANALYSIS \\
\hline $\begin{array}{c}\text { Source of } \\
\text { variance }\end{array}$ & $\begin{array}{c}\text { Sum of squares of } \\
\text { deviation from } \\
\text { mean }\end{array}$ & $\begin{array}{c}\text { Degree } \\
\text { of } \\
\text { freedom }\end{array}$ & F-Ratios & Otherness \\
\hline $\begin{array}{c}\text { Crushing } \\
\text { degree } \\
\text { Amount of } \\
\text { added water } \\
\text { Distillation } \\
\text { time }\end{array}$ & 0.466 & 2 & 1.043 & $p<0.01$ \\
\hline
\end{tabular}

adenocarcinoma SGC-7901 cell lines were purchased from Shanghai Yanhui Biotech Co., Ltd. and MTT, DMSO were provided by Shanghai Sangon Biotech Co., Ltd.

Cell culture: SGC-7901 cells were cultured conventionally in the penicillin-streptomycin antibiotic HyQ RP-MI-1640 medium containing $10 \%$ fetal bovine serum, concentration of penicillin was $100 \mu / 100 \mathrm{~mL}$ and concentration of streptomycin $100 \mu \mathrm{g} / \mathrm{mL}$. The temperature of incubator was maintained at $37{ }^{\circ} \mathrm{C}$, with $5 \% \mathrm{CO}_{2}$ and $98 \%$ relative humidity. Cells were grown adherently in monolayers, when they were grown up to $80-90 \%$ confluence, they were digested and subcultured with digestive juice containing $0.25 \%$ trypsin and $0.02 \%$ EDTA, cells in the logarithmic growth phase were collected and used in the experiment.

Cell proliferation test with MTT assay: SGC-7901 cells in logarithmic growth phase were seeded in 96-well plate at a concentration of $1 \times 10^{4} /$ well, $200 \mu \mathrm{L} /$ well and cultured at $37{ }^{\circ} \mathrm{C}$, under $5 \% \mathrm{CO}_{2}, 95 \%$ relative humidity. After cell adhesion, medium was replaced with Curcuma zedoaria oil medium. Experimental groups A, B, C, D were set up, A was the control group, other groups were added with Curcuma zedoaria oil medium containing 10,30 and $100 \mu \mathrm{g} / \mathrm{mL}$ of curcumol, respectively and culture medium containing $1 \%$ anhydrous ethanol was served as the negative control group E, $200 \mu \mathrm{g} /$ well, each concentration had 8 replicate wells. The experiment was repeated three times. Cells were cultured for $24,48,72 \mathrm{~h}$, respectively, $20 \mu \mathrm{L}$ of $5 \mathrm{mg} / \mathrm{mL}$ MTT was added to each well and the plates were sent back to the incubator and cultured for 4 more hours, culture medium was extracted and DMSO was added to each well at $150 \mu \mathrm{L}$ per well, the plates were incubated for $0.5 \mathrm{~h}$, after shaken on the microplate shaker for $1 \mathrm{~min}$, OD values at $570 \mathrm{~nm}$ were determined.

Determination of cell cycle: Cell cycle was analyzed with flow cytometry, that is, SGC-7901 cells treated for $48 \mathrm{~h}$ with Curcuma zedoaria oil containing 0, 10, 30 and $100 \mu \mathrm{g} / \mathrm{mL}$ curcumol were collected, washed twice with PBS, added with $-4{ }^{\circ} \mathrm{C}$ ice-cold $75 \%$ ethanol and fixed at $4{ }^{\circ} \mathrm{C}$ overnight; ethanol was discarded and cells were washed once with PBS, added with $100 \mu \mathrm{g} / \mathrm{mL}$ RNase and PI staining reagent, then stained for $20 \mathrm{~min}$ in dark conditions, changes in cell cycle were detected using flow cytometry.

Detection of cell apoptosis: Cell apoptosis was analyzed with flow cytometry, that is, SGC-7901 cells treated for $48 \mathrm{~h}$ with Curcuma zedoaria oil containing 0, 10,30 and $100 \mu \mathrm{g} / \mathrm{mL}$ curcumol were collected, washed twice with PBS and resuspended with $250 \mu \mathrm{L}$ of binding buffer to make cell concentration to be $1 \times 10^{5} \mathrm{~mL}$. $100 \mu \mathrm{L}$ of cell suspension was added into the $5 \mathrm{~mL}$ flow tubes, each tube was added with $5 \mu \mathrm{L}$ of AnnexinV/FITC and $5 \mu \mathrm{L}$ of $20 \mu \mathrm{g} / \mathrm{mL}$ propidium iodide, mixed evenly in dark conditions and labeled for $15 \mathrm{~min}$. Annexin V was not added to the control group and served as the correction factor. Reaction tube was added with $400 \mu \mathrm{L}$ of PBS and detected using fluorescence-activated cell sorting (FACS); the results were analyzed with random software.

Morphological observation of electron microscopy SGC7901 cells $c a .1 \times 10^{6}$ each bottle were seeded in $50 \mathrm{~mL}$ culture flasks, cultured for $24 \mathrm{~h}$. Adding a $30 \mu \mathrm{g} / \mathrm{mL}$ the Curcuma oil, were cultured $0,6,12,18$ and $24 \mathrm{~h}$, centrifuged for $5 \mathrm{~min}$, collected adherent and suspension cells, the cell pellet fixed with $215 \%$ glutaraldehyde, then fixed $1 \%$ osmium tetroxide, ethanol dehydration, embedded in epon 812 epoxy resin, sliced, ultrathin sections were double stained with uranyl acetate and lead citrate and observed the morphological changes by transmission electron microscopy.

Statistical methods: Statistics were conducted using SPSS 12 statistical software, $p<0.05$ was regarded as statistically significant.

\section{RESULTS AND DISCUSSION}

Effect of Curcuma zedoaria oil on proliferation of human gastric cancer SGC-7901 cells: The detection of the human gastric cancer SGC-7901 cells treated for $48 \mathrm{~h}$ with different concentrations of Curcuma zedoaria oil by MTT assay showed that, proliferation inhibition activities of different concentrations of Curcuma zedoaria oil were significantly enhanced in a concentration dependent manner, which showed significant differences $(p<0.05)$ compared with the control group, cell proliferation inhibition rates are shown in Table-4.

Effect of Curcuma zedoaria oil on proliferation cycle of human gastric cancer SGC-7901 cells: The results (Table5) showed that the Curcuma zedoaria oil could reduce the 


\begin{tabular}{lc}
\hline \multicolumn{2}{c}{ TABLE-4 } \\
COMPARISON OF INHIBITORY ACTION OF \\
Curcuma zedoaria OIL ON HUMAN GASTRIC \\
CANCER SGC-7901 CELL PROLIFERATION \\
\hline \multicolumn{1}{c}{ Group } & Inhibition rate (\%) \\
\hline A (control group) & $0.17 \pm 0.14$ \\
B (containing $10 \mu \mathrm{g} / \mathrm{mL}$ curcumol) & $8.03 \pm 2.41$ \\
C (containing $30 \mu \mathrm{g} / \mathrm{mL}$ curcumol) & $27.84 \pm 4.77$ \\
D (containing $100 \mu \mathrm{g} / \mathrm{mL}$ curcumol) & $69.32 \pm 4.96$ \\
\hline
\end{tabular}

TABLE-5

EFFECT ON SGC-7901 CELL PROLIFERATION CYCLE IN EACH EXPERIMENTAL GROUP $(\bar{x} \pm s, \%)$

\begin{tabular}{ccccc}
\hline $\begin{array}{c}\text { Experimental } \\
\text { group }\end{array}$ & $\mathrm{n}$ & $\mathrm{G}_{0} / \mathrm{G}_{1}$ & $\mathrm{~S}$ & $\mathrm{G}_{2} / \mathrm{M}$ \\
\hline $\mathrm{A}$ & 3 & $57.18 \pm 0.63$ & $35.46 \pm 1.51$ & $7.36 \pm 0.79$ \\
$\mathrm{~B}$ & 3 & $66.74 \pm 0.88^{*}$ & $28.64 \pm 1.65^{*}$ & $4.62 \pm 1.32$ \\
$\mathrm{C}$ & 3 & $73.66 \pm 1.41^{*}$ & $20.92 \pm 0.87^{*}$ & $5.42 \pm 1.23^{*}$ \\
$\mathrm{D}$ & 3 & $85.02 \pm 1.88^{*}$ & $12.89 \pm 0.77^{*}$ & $2.09 \pm 0.58^{*}$ \\
\hline
\end{tabular}

proportion of tumor cells in $\mathrm{S}$ and $\mathrm{G}_{2} / \mathrm{M}$ phases and increase the proportion of tumor cells in $\mathrm{G}_{0} / \mathrm{G}_{1}$ phase, moreover, the number of tumor cells arrested in $\mathrm{G}_{0} / \mathrm{G}_{1}$ phase increased with the increase of curcumol concentration, of which the experimental group D (containing $100 \mu \mathrm{g} / \mathrm{mL}$ curcumol) showed the strongest effect.

Effect on apoptosis of human gastric cancer SGC-7901 cells in each experimental group: The results showed the apoptosis of tumor cells after intervention for $48 \mathrm{~h}$ with different concentrations of curcumol. The control group only had a very small amount of apoptotic cells. The rate of tumor cell apoptosis gradually increased with the increase of curcumol concentration, while normal cells gradually decreased. Among the four experimental groups, the group containing $100 \mu \mathrm{g} /$ $\mathrm{mL}$ curcumol had the strongest apoptotic activity, as shown in Table-6.

\begin{tabular}{cccccc}
\multicolumn{7}{c}{ TABLE-6 } \\
\multicolumn{7}{c}{$\begin{array}{c}\text { EFFECT ON SGC-7901 CELL APOPTOSIS IN } \\
\text { EACH EXPERIMENTAL GROUP }(\overline{\mathrm{x}} \pm \mathrm{s}, \%)\end{array}$} \\
\hline $\begin{array}{c}\text { Exp. } \\
\text { group }\end{array}$ & $\mathrm{n}$ & $\begin{array}{c}\text { Normal } \\
\text { cells }\end{array}$ & $\begin{array}{c}\text { Early apoptotic } \\
\text { cells }\end{array}$ & $\begin{array}{c}\text { Late apoptotic } \\
\text { cells }\end{array}$ & $\begin{array}{c}\text { Necrotic } \\
\text { cells }\end{array}$ \\
\hline A & 3 & 86.45 & 5.68 & 4.67 & 3.2 \\
B & 3 & $54.26^{*}$ & $21.76^{*}$ & $16.57^{*}$ & 7.41 \\
C & 3 & $48.59^{*}$ & $25.78^{*}$ & $22.71^{*}$ & 2.92 \\
D & 3 & $25.57^{*}$ & $29.54^{*}$ & $36.98^{*}$ & $7.91^{*}$ \\
\hline
\end{tabular}

Morphological changes of SGC-7901 observed with the electron microscope: Through electron microscopy, the SGC7901 cells in not plus drug group were complete and the cells were slightly irregular shape, cell surface had microvilli, Nuclei were irregular in shape, prominent nucleoli, there were mitochondria, rough endoplasmic reticulum and glycogen granules in the cell cytoplasm (Fig. 1A), the SGC-7901 cells exposed to Curcuma oil $(30 \mu \mathrm{g} / \mathrm{mL})$ for $12 \mathrm{~h}$ showed the typical features of apoptosis, cell surface microvilli disappear, cytoplasmic vacuolization, nuclear chromatin condensation and margination, chromatin is highly condensed chromatin blocks concentrated, the nuclear fragmentation, split gathering chromatin block to a number of nuclear debris, as shown in Fig. 1B.
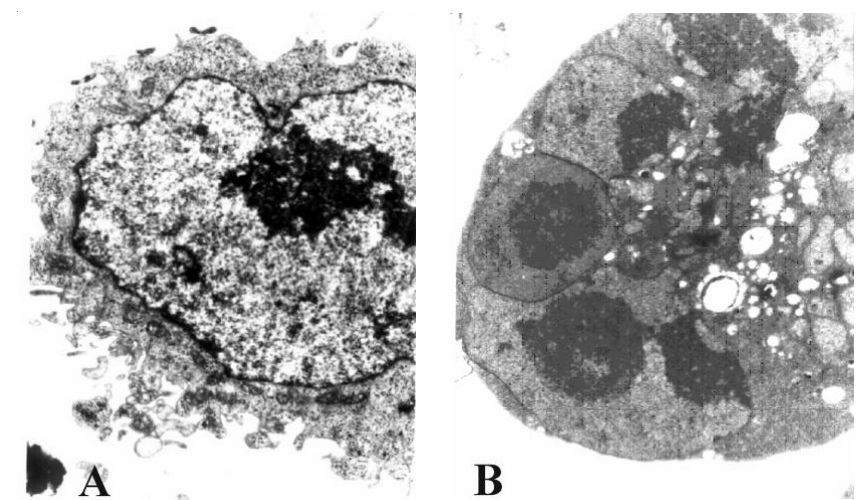

Fig. 1. Morphological changes of SGC-7901 induced by Curcuma oil observed with the electron microscope. A negative control group; B SGC-7901 exposed to Curcuma oil $(30 \mu \mathrm{g} / \mathrm{mL})$ for $12 \mathrm{~h}$

The orthogonal experimental results showed that the optimum conditions for the extraction of Curcuma zedoaria oil were crushing degree of (40-80) mesh, amount of added water of 40 folds and distillation time of $2 \mathrm{~h}$. The verification experiment showed that the extraction rate reached its highest level when the Curcuma zedoaria powder below 40 mesh was added with water 40 times its volume and extracted for $4 \mathrm{~h}$. Taking into consideration the energy consumption in crushing, water conservation and other factors, the optimum processing conditions should be Curcuma powder below 20 mesh, water addition of 20 folds and extraction time of $4 \mathrm{~h}$.

It was found in the experiment that the prolonged distillation could easily lead to the turbidity of volatile oil. It may be due to relatively high amount of starch granules contained in the Curcuma zedoaria, which can easily be distilled off with water vapor and volatile oil during the prolonged heating and distillation process, resulting in large amounts of bubbles in the extracted volatile oil and easy formation of turbid emulsion by oil and water. In addition, the main active ingredient of Curcuma zedoaria volatile oil is sesquiterpene derivatives, prolonged heating can cause decomposition and transformation of these derivatives, affecting their anticancer effects. Therefore, the control of distillation time and temperature during the experiment greatly impacts the experimental results.

Kerr et al. ${ }^{4,5}$ discovered a mode of cell death significantly different from necrosis, which was later named as apoptosis. Apoptosis is a spontaneous cell death process controlled by genes which is triggered in response to physiological and pathological stress stimuli ${ }^{6,7}$; it has great significance to the tissue differentiation, organ development and maintenance of body stability in multi-cellular organisms ${ }^{8}$. As an important form of cell death, apoptosis has an important role in maintaining normal development of body, while apoptosis disorders and cell cycle abnormalities are important causes for tumorigenesis ${ }^{9,10}$. It can be said that the formation of gastric cancer is due to excessive proliferation and reduced apoptosis of tumor cells. At present, the main means of treatment of tumors is the interference of cell cycle of tumor cells, so as to slow down the proliferation speed of tumor cells or induce programmed cell death ${ }^{11}$. In recent years, it was unexpectedly found during the application of gene knockout technology that the removal of PI3K-p110 $\beta$ could effectively inhibit malignant cell proliferation $^{12-14}$. 
In recent years, there are many reports about Curcuma oil having antitumor effects at home and abroad. During vitro antitumor screening for curcuma, we found the Curcuma oil can significant inhibit a variety of tumor cell proliferation. Gastric cancer is one of the China's high incidence of malignancy, The study choose human gastric adenocarcinoma (SGC7901) cells as an in vitro experimental model in order to observe in depth the effect of extracted Curcuma zedoaria oil on tumor cells.

This study found that the curcumol had a significant inhibitory effect on the proliferation of SGC-7901 cells and could induce apoptosis. Its inhibition of SGC-7901 cell proliferation is mainly due to the retardation of $\mathrm{G}_{0} / \mathrm{G}_{1}$ phase, $\mathrm{G}_{0} / \mathrm{G}_{1}$ phase is the prophase of DNA synthesis, which is also known as the anaphase of cell division, $G_{1}$ phase mainly prepares for the transition to $\mathrm{S}$ phase, that is, prepares for the next step of DNA replication and protein synthesis, $\mathrm{G}_{1}$ phase is the key phase of cell cycle, as long as the amount of positive regulatory protein synthesis is accumulated to a certain extent within $G_{1}$ phase, the cells will no longer be dependent on the survival of extracellular growth factor and will successfully complete the entire cell cycle. The results of this experiment suggest that the Curcuma zedoaria oil can significantly inhibit the proliferation of SGC-7901 cells and its inhibitory effect is positively correlated with drug concentration.

\section{REFERENCES}

1. J.J. Johnson and H. Mukhtar, Cancer Lett., 255, 170 (2007).

2. N. Kheeree, P. Sangvanich, S. Puthong and A. Karnchanatat, Appl. Biochem. Biotechnol., 162, 912 (2010).

3. N.-H. Loc, D.-T.-H. Diem, D.-H.-N. Binh, D.-T. Huong, T.-G. Kim and M.S. Yang, Mol. Biotechnol., 38, 81 (2008).

4. T. Suda, T. Takahashi, P. Golstein and S. Nagata, Cell, 75, 1168 (1993).

5. M. Steel, Lancet, 342, 754 (1993).

6. M.K. Collins, G.R. Perkins, G. Rodriguez-Tarduchy, M.A. Nieto and A. Lopez-Rivas, Bioessays, 16, 133 (1994).

7. S. Tanaka and J.R. Wands, Cancer Res., 56, 3391 (1996).

8. L. Sun, F. Wang, H. Sun, X.P. Le, L.X. Liu, Y.F. Liu, F. Wang, Y.H. Wang, H.Y. Ma and Q.X. Zhang, Zhongguo Shi Yan Xue Ye Xue Za Zhi, 13, 605 (2005).

9. C.Y. Fung and D.E. Fisher, J. Clin. Oncol., 13, 808 (1995).

10. E.S. Guns, T. Denpssevpch, H. Dixon, M.B. Bally and L. Mayer, Eur. J. Drug Metab. Pharmacokinet., 27, 119 (2002).

11. C. Wu and J. Huang, J. Biol. Chem., 282, 3571 (2007).

12. M. Nyåkern, P.L. Tazzari, C. Finelli, C. Bosi, M.Y. Follo, T. Grafone, P.P. Piccaluga, G. Martinelli, L. Cocco and A.M. Martelli, Leukemia, 20, 230 (2006).

13. K. Pan, H. Wang, M.S. Chen, H.K. Zhang, D.S. Weng, J. Zhou, W. Huang, J.J. Li, H.F. Song and J.C. Xia, J. Cancer Res. Clin. Oncol., 134, 1247 (2008)

14. S. Jia, Z. Liu, S. Zhang, P. Liu, L. Zhang, S.H. Lee, J. Zhang, S. Signoretti, M. Loda, T.M. Roberts and J.J. Zhao, Nature, 454, 776 (2008). 